\title{
RESEARCH ON UNDERGROUND TUNNEL INTELLIGENT LIGHTING CONTROL TECHNOLOGY FOR ENERGY SAVING RAILWAY SYSTEM
}

\author{
JONGBIN PARK ${ }^{1}$, KYEONGSIK KIM $^{1}$, JUNGWOOK PARK ${ }^{2}$, BUSEOK KWON ${ }^{2}$, \\ CHANGSIK KIM ${ }^{3}$, JUNGHO KIM ${ }^{4}$, JAEMIN KIM ${ }^{5} \&$ WOOJIN JANG ${ }^{5}$ \\ ${ }^{1}$ Korea Institute of Lighting Technology, South Korea \\ ${ }^{2}$ Seoul Metro, South Korea \\ ${ }^{3}$ Vitzrosys, South Korea \\ ${ }^{4}$ Unilux, South Korea \\ ${ }^{5}$ Seoul National University of Science and Technology, South Korea
}

ABSTRACT

Today, the climate is rapidly changing worldwide due to overuse of energy, and along with low-carbon green growth, the study is focusing on the development of renewable energy. Especially in case of urban railroads, the stations are built underground, in which dependence rate of artificial lighting is very high in the energy consumption ratio compared to other facilities. In order to solve this, the researchers replaced the fluorescent lighting equipment that is constantly lit in the tunnel section with high-efficiency LED lighting that controls dimming in conjunction with vehicle position information and the railway signalling system.

Keywords: energy saving, railroad signal system, metro, LED lighting, fluorescent lighting fixtures, intelligent lighting control system, CPLC, bluetooth, zigbee, LTE.

\section{INTRODUCTION}

Lighting equipment, which is one of the representative facilities of railway facilities, is a core facility of railway that ensures the safety, comfort, promptness and convenience of railway workers and users, but also occupies a very high part of power consumption of railway facilities. Therefore, improvement of lighting equipment's efficiency has been required.

In recent years, with the development and supply spreads of LED lighting, which is a high-efficiency and high-performance light source, replacements and introduction of LED lighting fixtures in existing lighting fixtures including fluorescent lighting fixtures are under progress worldwide due to demands for replacing deteriorated lighting facilities of railway facilities and construction of new railway network. However, it is found that, most lighting fixtures occupy traditional lighting fixtures, including fluorescent lighting fixtures.

As for the operation flow of the lighting equipment in the underground tunnel section of Korea's urban railway, the lighting equipment used in most underground tunnel sections except for the new routes such as BUNDANG Line has used the fluorescent lamp apparatus. In recent years, due to the development and dissemination of LED lighting as well as environmental demands such as energy saving and greenhouse gas reduction [1], existing lighting fixtures has been actively replaced to LED lighting fixtures. Especially, maximization of control efficiency through intelligent system control, such as smart control, is under active research and developments. This is because the dimming control, which was not possible with conventional fluorescent lighting fixtures, can be achieved through the replacement with LED lighting, which makes it possible to operate as more efficient lighting control method than the existing 'On / Off' control method.

In this study, it considers an intelligent lighting control system that automatically controls lighting according to the position of a train in order to maximize energy savings and discuss 

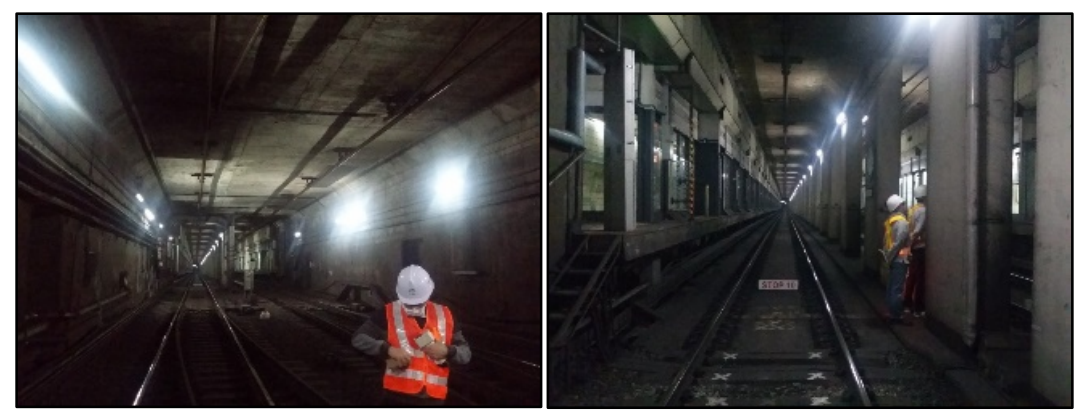

Figure 1: Seoul Metro (South Korea) underground tunnel LED lights.

efficient lighting control methods linked to a railway signalling system as a key information collecting device. [2]

\section{RESEARCH ON INTELLIGENT LIGHTING CONTROL}

As mentioned in the introduction, to accomplish the purpose of this study, train position information is collected by using the closed signal of the railway system, and the information is safely transmitted to the lighting control system. Then, the following research was conducted on the intelligent lighting control method that effectively controls the lighting facilities installed on railway lines individually or collectively through the lighting control algorithm.

\subsection{Comparison of lighting fixtures}

Fluorescent lamps used in fluorescent lighting fixtures have a nominal life of approximately 8,000 to 12,000 hours, which makes it difficult to control the dimming and vulnerable to 'On / Off' environments. In case of LED lighting, it guarantees rated life about at least 30 000 50 000 hours, and has dimming control, has excellent in 'On / Off' environment, and various controls are possible. Table 1 shows comparisons of optical and electrical performances of lighting fixtures.

Table 1: Comparison table of lighting fixtures.

\begin{tabular}{|c|c|c|c|c|c|c|}
\hline $\begin{array}{c}\text { Product } \\
\text { name }\end{array}$ & $\begin{array}{c}\text { Lamp type/ } \\
\text { power(W) }\end{array}$ & $\begin{array}{c}\text { Total } \\
\text { luminous } \\
\text { flux }(1 \mathrm{~m})\end{array}$ & $\begin{array}{c}\text { Light } \\
\text { efficiency } \\
(\mathrm{lm} / \mathrm{W})\end{array}$ & $\begin{array}{c}\text { Color } \\
\text { rendering } \\
\text { index }\end{array}$ & $\begin{array}{c}\text { Color } \\
\text { temperature } \\
(\mathrm{K})\end{array}$ & Photo \\
\hline $\begin{array}{c}\text { Fluorescent } \\
\text { lighting } \\
\text { fixture }\end{array}$ & $\begin{array}{c}\text { Fluorescent } \\
\text { lamp/ }\end{array}$ & 1684 & 57 & 81 & 6117 & \\
\hline $\begin{array}{c}\text { LED } \\
\text { lighting } \\
\text { fixtures }\end{array}$ & $\begin{array}{c}\text { LED tube/ } \\
17 \mathrm{~W}\end{array}$ & 2108 & 112 & 85 & 5843 & \\
\hline
\end{tabular}




\subsection{Conventional lighting equipment control method}

Conventional lighting equipment control method was able to control 'On / Off' through the switchboard in the electric room adjacent to the station. However, since there is a minimum illumination standard in the subway tunnel section of the city railway, it operates in the form of constant lighting.

\subsection{Lighting control equipment connected with railroad signal system}

Consideration to improve the energy efficiency by dimming control according to the position of the vehicle by means of efficient lighting control has been taken. In order to collect the position information of the vehicle, instead of adding a sensor or a separate position sensing function, it considered the method of collecting the position information of the train using the railroad signal system's block signal and transmitting the information to each lighting facility for control.

Because these systems are used in all rail systems to locate the vehicle, it is advantageous to obtain accurate vehicle location data without expensive sensing equipment or additional cost. [3]

\subsection{Railroad signal system}

The railroad signal system monitors the progress of a train in real time and confirms automatic route setting, train evacuation, interchange, speed of operation, mistake of driver, system failure, securing safety first; it is a key system for operation improvement of the train.

\subsection{Collecting block signal information}

In the railroad signalling system, a block section is defined through a block device, and when the train enters, a block device prevents other trains from entering the section, which is called a block equipment. Fig. 2 shows a conceptual diagram of the fixed block system. The block section interval is divided to establish the orbit, and it refers to a method of detecting a train track by which it occupies a certain track circuit and automatically sends a signal display or a car signal to a trailing train.

Fig. 3 is a conceptual diagram of a track circuit device. It uses train-to-terrestrial communication to control the speed of a train in a fixed-closure manner. It consists of an electric circuit and the circuit is connected to the track circuit automatically detects the presence or absence of a train.

The information of train position detected in real time can be confirmed by the train position monitoring system of the signalling machine room. Finally, information arrives at the train control system and is used as information for various control of the train.

\subsection{Delivery of location information}

Using the above-mentioned train occupancy detection method, information is collected in the train position monitoring system of the signal machine room as shown in Fig. 5, and control signals for each lighting are transmitted to control the lighting of the front tunnel section according to the train movement. 


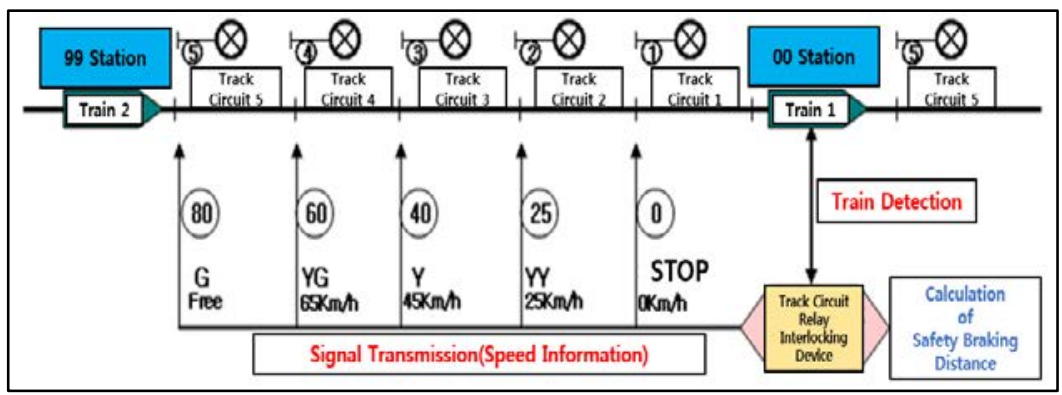

Figure 2: Fixed block system conceptual diagram.

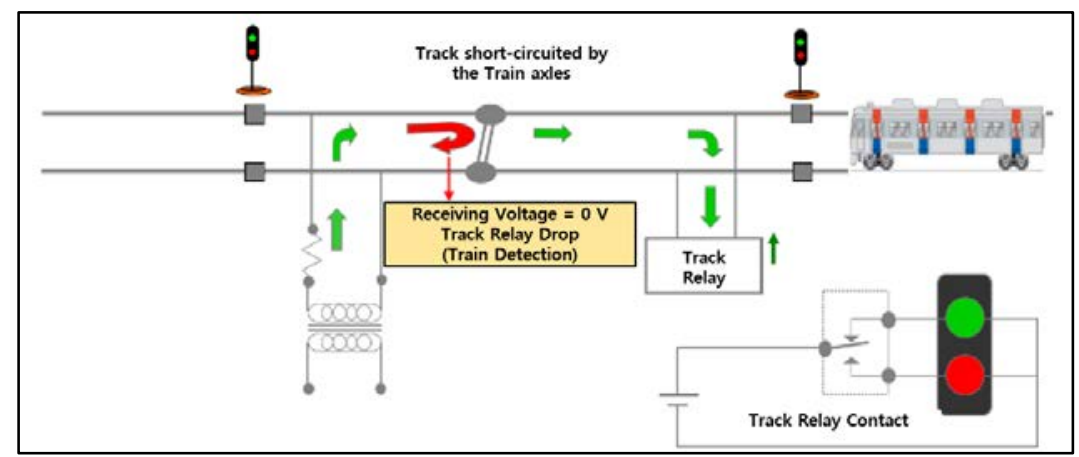

Figure 3: Track relay conceptual diagram.

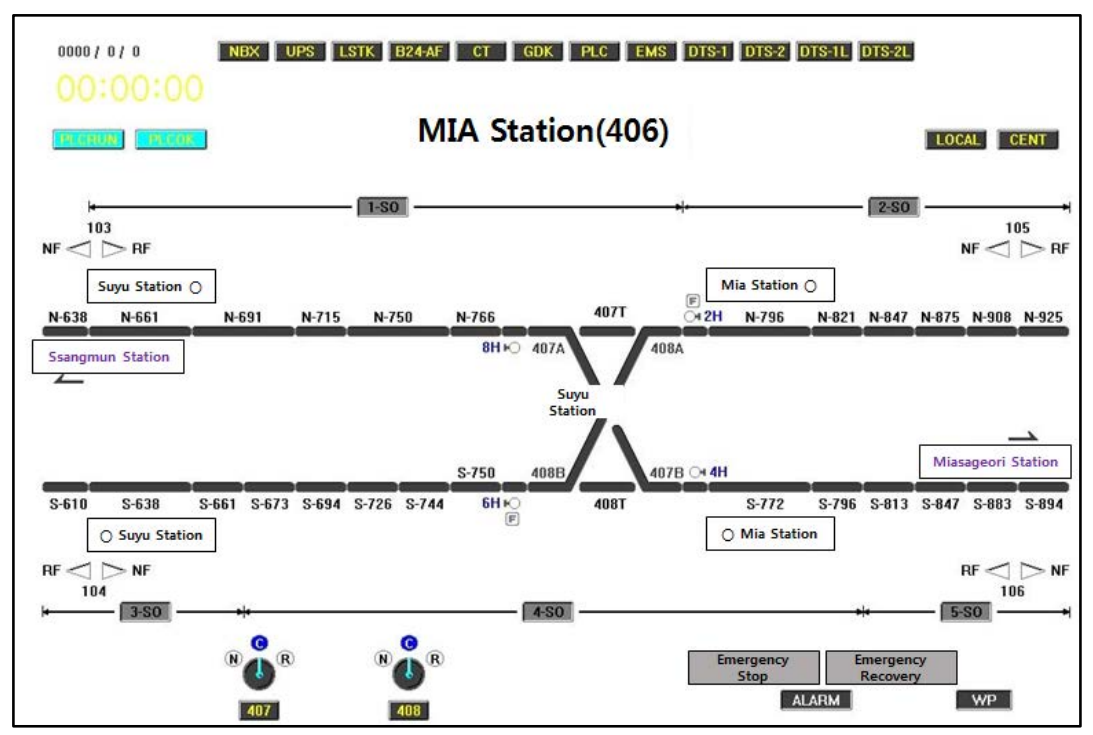

Figure 4: Train position monitoring system. 


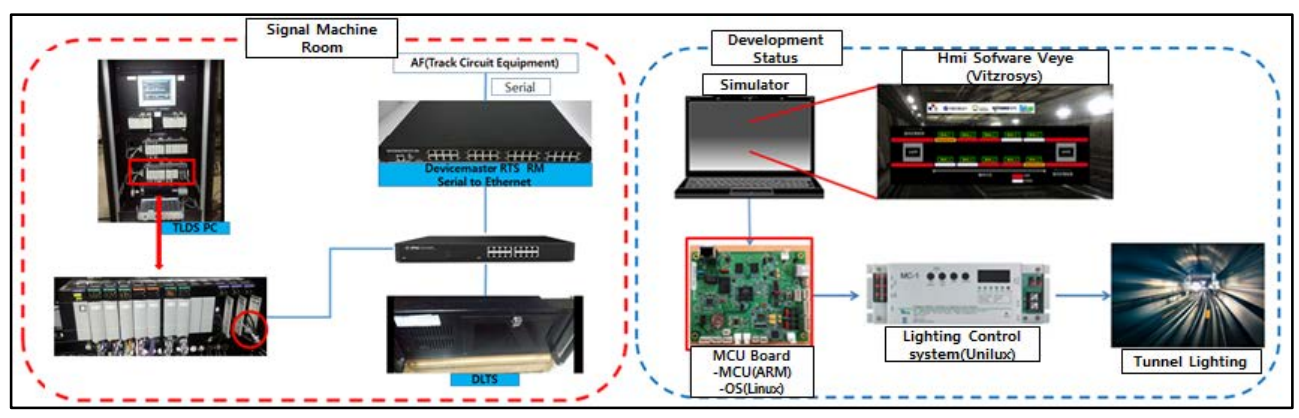

Figure 5: System schematic.

In order to construct the above system, it was necessary to develop a technology for transferring the train position information collected by the train position monitoring system to the lighting control system safely. Korea is required to process information technology and technology.

As shown in the Fig. 6, it chose to use VPN (Virtual Private Network), one of the security solutions, to transmit information to the lighting control system.

VPN is a technology for obtaining the effect of replacing expensive private network by using the Internet. In Korea, the urban railway uses the closed network in the subway, so there is no security problem. However, in case of transmission, security vulnerability may occur. Therefore, security enhanced system is configured using an SSL VPN (Secure Sockets Layer Virtual Private Network) server.

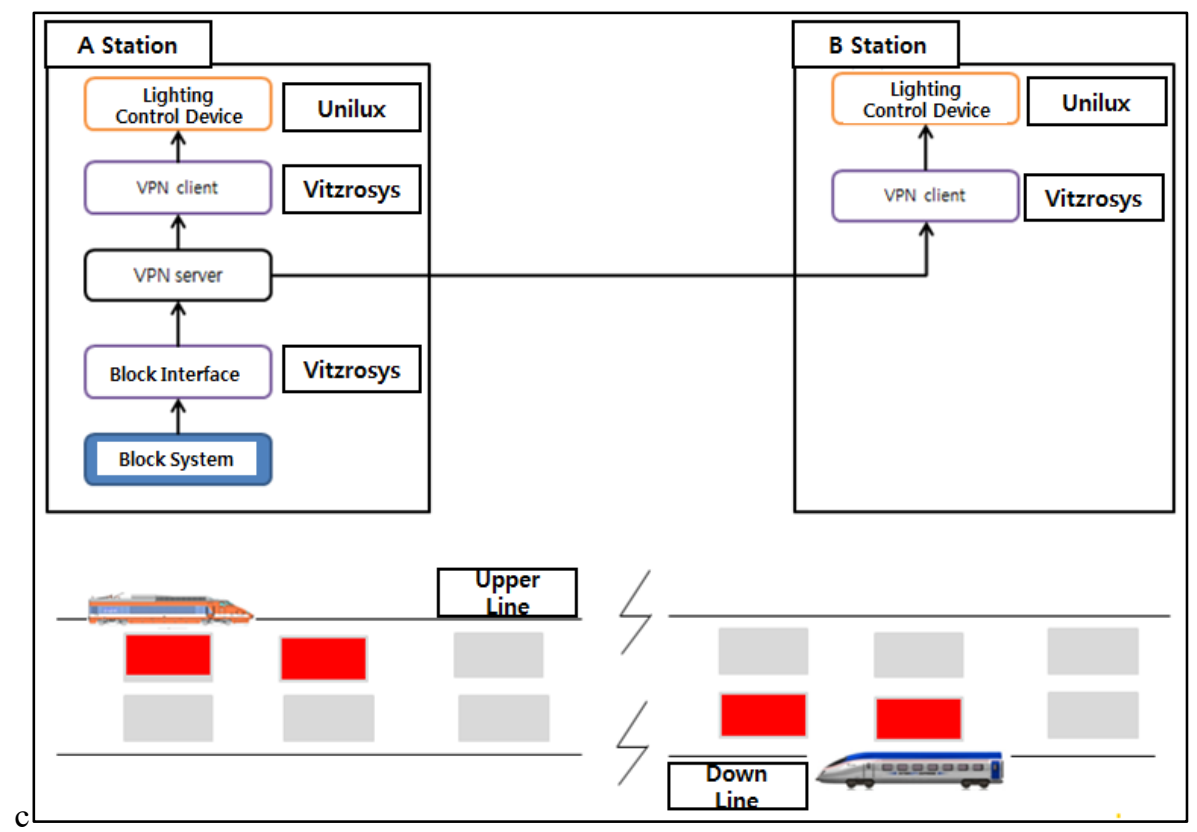

Figure 6: VPN applied configuration. 
Using the railway signalling system as described above solves the problem of collecting train information, but it must consider how to send collected information to individual lighting facilities.

Recently, various communication control solutions such as Wifi, ZigBee, Bluetooth and LTE have been provided. However, since the underground tunnel section of the urban railway is a public facility to be used by multiple users, there are terrors and various risk factors it is difficult to apply the above solutions easily. Therefore, researches on how to handle the transmission of the position information of the railway signal system was required.

\subsection{Lighting control using CPLC method}

When applying the above-mentioned communication methods, there are various risk factors of communication within the urban railway tunnels in Korea, and it was cautious about the way of utilizing the existing power lines.

Conventional power line communication (PLC: Power Line Communication) is a power line communication using various bandwidths from 9 to $500 \mathrm{kHz}$. It uses a power line of $220 \mathrm{~V}$ and $60 \mathrm{~Hz}$, which is commonly used, and transmits a modulated signal containing information at a transmitter and the demodulation is performed again in the receiver. Since a signal must be demodulated, a dedicated PLC receiver is required. A very large $60 \mathrm{~Hz} \mathrm{AC}$ voltage inside an urban railway tunnel acts as a very large noise on the PLC modulated signal, resulting in poor communication environment. In addition, attenuation may occur rapidly depending on the grounding, the capacitance, and the wiring method. There may be a problem that the characteristic of the reflected wave easily changes due to the change of the input impedance or the output impedance of the transmission line depending on the load characteristic.

Closed circuit power line communication (CPLC: Closed circuit Power Line Communication) is a method that overcomes the disadvantages of the conventional PLC and is considered as a method for low-cost and high-efficiency lighting control. This communication method is simple in configuration and ensures high reliability. [3]

To individually control 64 lamps connected in parallel as shown in Fig. 7, the address 6 bits for identifying each lamp, 4 bits of 'On/Off/Dimming command, 8 bits of brightness data, total of 18 bits of information will be used for lighting control. Power line communication is possible only in the closed circuit using the phase control in the low voltage section immediately after the zero cross. No wiring other than the luminaire is needed because it is resistant to noise and the receiver circuit is simple. It is also advantageous that the price is low and the mounting area is small. The CPLC method was considered to be suitable for the construction of the smart lighting control system inside the urban railway tunnel. [3]

\subsection{Smart lighting control system}

Even if the control is selected by the CPLC method, it is necessary to develop an intelligent lighting control system for efficient and systematic control.

The intelligent lighting control system utilizes the closed-circuit power line communication method (CPLC) according to the set lighting control algorithm.

It is necessary to design an optimized algorithm that can perform functions such as “On/Off” Dimming control, Maintenance control, etc., individually or collectively, and UI (User Interface) that is easy to operate is required. 


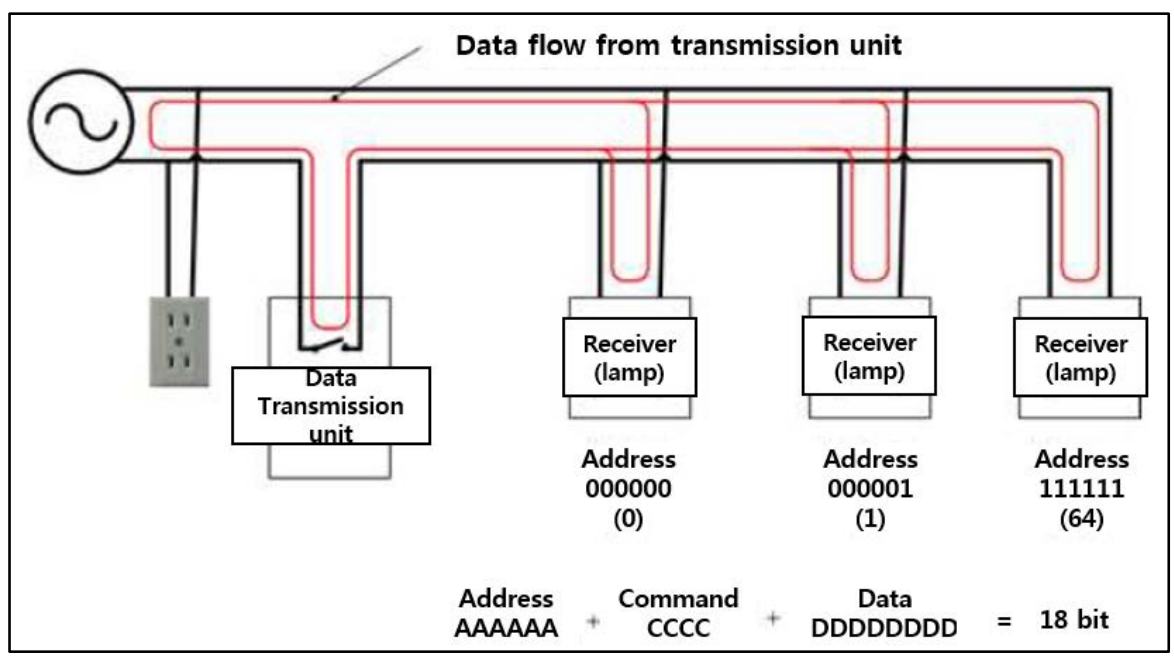

Figure 7: CPLC (Closed circuit power line communication method).

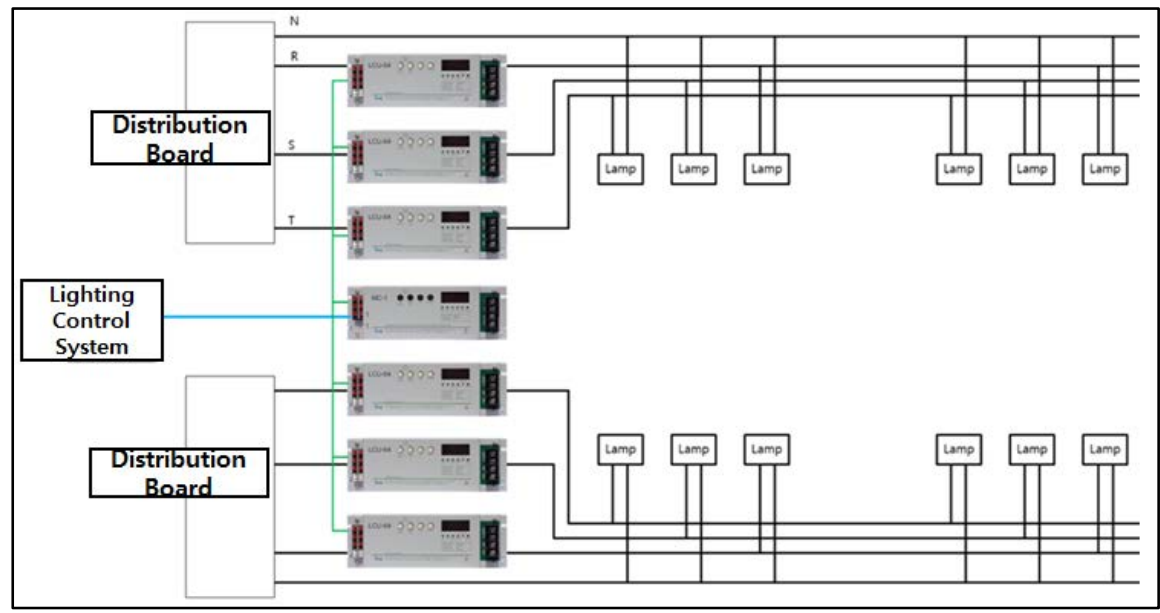

Figure 8: Lighting control using CPLC communication (example).

\subsection{Lighting control algorithm}

Even if the transmission of position information is resolved, it is necessary to construct an optimal lighting control algorithm according to the position of the railroad vehicle. To achieve effective control, the lighting control algorithm includes settings of various factors such as train time, position, type of train, and composition of train. However, the current system is the initial version and it is designed considering some commends as shown in Table 2, which includes the number of block sections, length, quantity of lighting facilities, direction of train, etc.; it will add more commends through further study in the future. 
Table 2: Lighting control algorithm instruction.

\begin{tabular}{|c|c|c|}
\hline Division & Command & Explanation [Byte] \\
\hline \multirow{3}{*}{$\begin{array}{l}\text { Block } \\
\text { section } \\
\text { information }\end{array}$} & Total_Block_Section_No & Number of total block sections [1Byte] \\
\hline & Block_Section_Length & $\begin{array}{l}\text { Length of each block section } \\
\text { [Total_Block_Section_No } * 2 \text { Byte] }\end{array}$ \\
\hline & NodeNo_of_eack_Block & $\begin{array}{l}\text { Quantity of each block section } \\
\text { [Total_Block_Section_No* Max_Lamp } \\
* \text { 1Byte] }\end{array}$ \\
\hline \multirow{7}{*}{$\begin{array}{l}\text { Control } \\
\text { information }\end{array}$} & $\begin{array}{l}\text { Min_Lighting_Forward } \\
\text { _Distance }\end{array}$ & $\begin{array}{l}\text { Minimum distance to be lit in front of the } \\
\text { train [2Byte] }\end{array}$ \\
\hline & $\begin{array}{l}\text { Min_Lighting_Backward } \\
\text { _Distance }\end{array}$ & $\begin{array}{l}\text { The minimum distance that should be lit } \\
\text { from the rear of the train [2Byte] }\end{array}$ \\
\hline & Dim_Level_Backward & $\begin{array}{l}\text { Brightness of lighting when lighting from } \\
\text { rear [1Byte] }\end{array}$ \\
\hline & Emergency_Judge_Time & $\begin{array}{l}\text { If there is no change more than the setting } \\
\text { time (minute) with the block section } \\
\text { turned on, it is judged as an emergency } \\
\text { situation and all lights [1Byte] }\end{array}$ \\
\hline & Max_Lamp & $\begin{array}{l}\text { Maximum number of lamps installed in } \\
\text { the block section [1Byte] }\end{array}$ \\
\hline & Train_Direction & $\begin{array}{l}\text { Direction of travel of train (1: direction } \\
\text { approaching reverse, } 0 \text { : direction away } \\
\text { from station) } \\
* \text { Each block section information should } \\
\text { be placed in a fast array nearest to the } \\
\text { station }\end{array}$ \\
\hline & All_On_after_OP_Time & $\begin{array}{l}\text { Time until all lights are turned on after } \\
\text { operation stop. If it is " } 0 \text { ", do not turn on } \\
\text { [Minute, 1Byte] }\end{array}$ \\
\hline
\end{tabular}

Fig. 9 shows the basic configuration of the lighting control algorithm and based on the setting of the lighting control algorithm, the lighting facility is intelligently controlled according to the train position information as shown in Fig. 10.

\section{SIMULATION VERIFICATION}

All of the systems require verification, and because the development of the system requires verification of what economic and environmental effects are expected, it conducted a series of simulation techniques. 


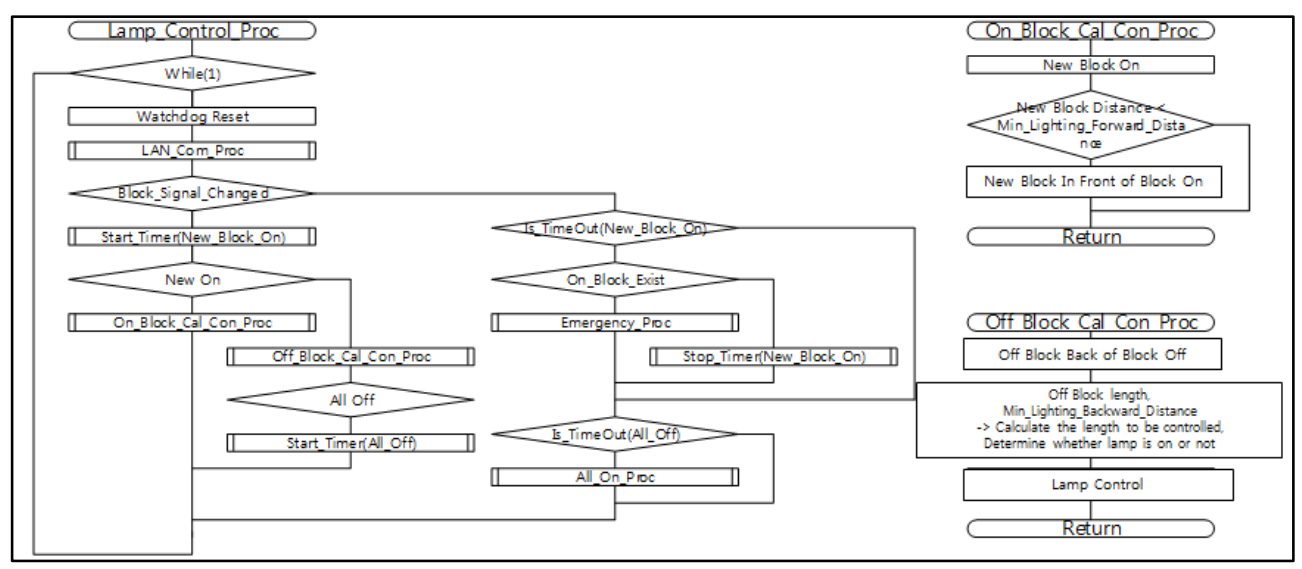

Figure 9: Basic configuration of the lighting control algorithm.

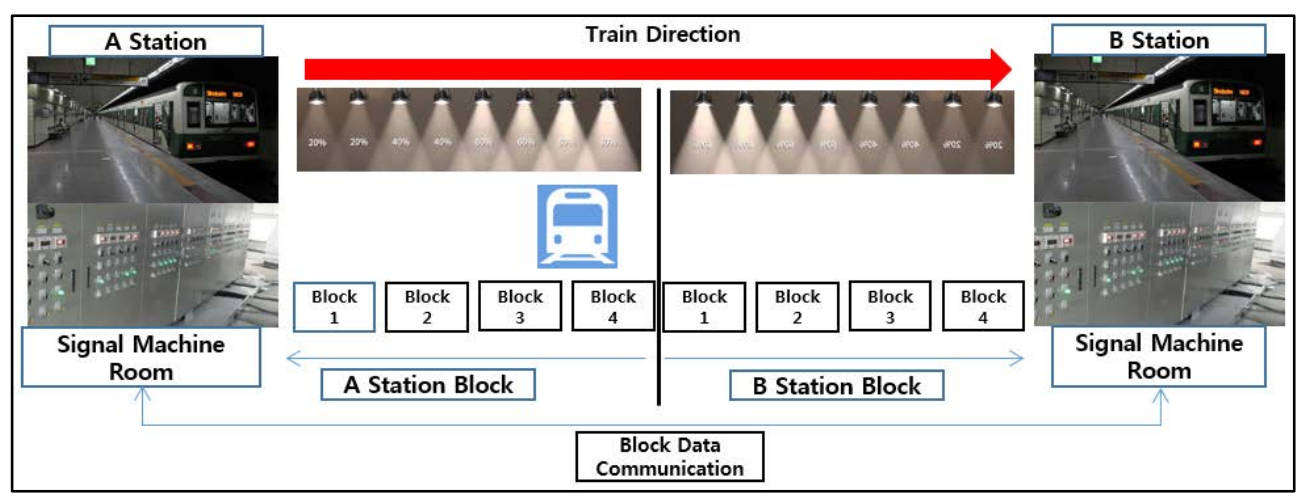

Figure 10: Lighting control based on lighting control algorithm.

\subsection{Simulation}

Simulation was carried out to check the amount of lighting fixtures when light was turned on for two block section ahead of the entrance to the block section of the train, and $20 \%$ of dimming control was applied to the rest of the lighting.

For example, assuming that there are five blocks between two, the total block is divided into block A to block E, and the total number of illumination is set to 61. Fig. 11 shows results when train enters the obstruction B.

Table 3 shows the simulation results assuming that the train is located at each block section under the same conditions.

If the above lighting control is performed, the power consumption of existing lighting equipment is reduced by an average of $57 \%$. 


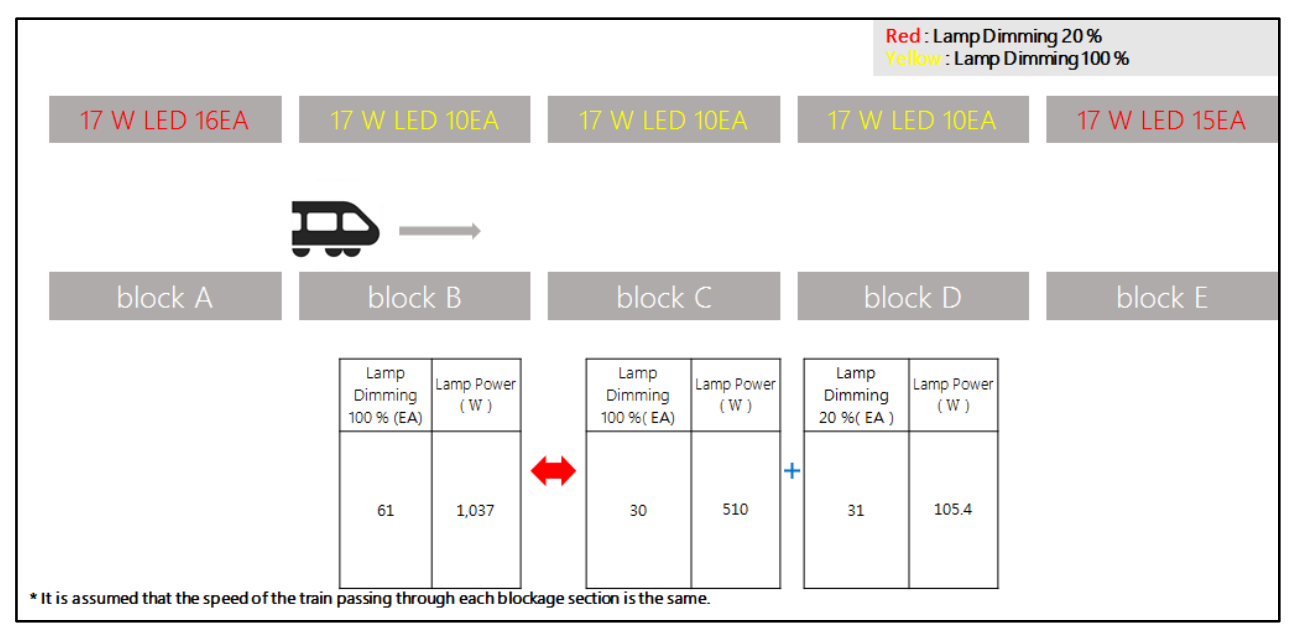

Figure 11: Simulation example.

Table 3: Simulation result value.

\begin{tabular}{|c|c|c|c|c|c|c|c|c|c|}
\hline \multirow[t]{2}{*}{ Block } & \multirow{2}{*}{$\begin{array}{l}\text { Lamp Dimming } \\
\qquad \begin{array}{l}100 \% \\
(E A)\end{array}\end{array}$} & \multirow{2}{*}{$\begin{array}{l}\text { Lamp Power } \\
\text { (W) }\end{array}$} & \multirow{3}{*}{ Block } & \multicolumn{2}{|c|}{$\begin{array}{c}\text { Lamp Dimming } \\
100 \%\end{array}$} & \multicolumn{2}{|c|}{$\begin{array}{l}\text { Lamp Dimming } \\
20 \%\end{array}$} & \multirow{3}{*}{ Lamp Power } & \multirow{3}{*}{$\begin{array}{c}\text { Reduction } \\
\text { ratio[\%] }\end{array}$} \\
\hline & & & & & Lamp & & Lamp & & \\
\hline A & \multirow{5}{*}{61} & \multirow{5}{*}{1,037} & & $(E A)$ & $\begin{array}{c}\text { Power } \\
\text { (W) }\end{array}$ & $(E A)$ & $(W)$ & & \\
\hline B & & & A & 36 & 612 & 25 & 85 & 697 & 67 \\
\hline C & & & B & 30 & 510 & 31 & 105.4 & 615.4 & 59 \\
\hline D & & & C & 35 & 595 & 26 & 88.4 & 683.4 & 66 \\
\hline E & & & D & 25 & 425 & 36 & 122.4 & 547.4 & 53 \\
\hline Total & & 5,185 & $E$ & 15 & 255 & 46 & 156.4 & 411.4 & 40 \\
\hline & & & Total & - & 2,397 & - & 557.6 & $2,954.6$ & 57 \\
\hline
\end{tabular}

\subsection{Economic and environmental effects analysis}

Seoul Metro carried out the tunnel lighting replacement work from 2013 to 2015. [1] Based on Seoul Metro Line 5 8, Line 5, 51 subway sections, 8,070 EA, Line 6, 38 subway sections, 4,958 EA, tunnel lighting fixtures for 42 tunnels in line 7, 6,748 EA in subway section, Line 8,17 subway sections, 2,827 EA. 22,603 EA tunnels in 148 subway sections were replaced 
with LED lighting. The $32 \mathrm{~W}$ fluorescent lamps were applied as a $17 \mathrm{~W}$ class LED lighting fixture.

To carry out the economic and environmental analysis, it is assumed to have 21 hours per day for the train operating time, only one vehicle exists between the stations, and the light is always set as on-state. Then, it analyzed the effect of replacement to LED lighting fixtures from fluorescent lighting fixtures as shown in Table 4.

In this result, it applied 57\% reduction of power consumption of lighting fixtures obtained by simulation of control of lighting equipment according to the position of the preceding train as a reduction factor.

However, the value can change depending on how the lighting control is set up, and there are various variables such as the distance between the stations, the distance of the obstruction section, the quantity of lighting equipment installed in the block section, and the number of vehicles operating in the rush hour time.

Table 4: Analysis of Seoul Metro Line 5 8.

\begin{tabular}{|c|c|c|c|c|c|c|c|}
\hline Division & \begin{tabular}{|} 
Lighting \\
power \\
$(\mathrm{W} / \mathrm{EA})$
\end{tabular} & $\begin{array}{l}\text { Lighting } \\
\text { fixture } \\
\text { (EA) }\end{array}$ & \begin{tabular}{|c|} 
Power \\
consumption \\
$(\mathrm{kWh})$
\end{tabular} & $\begin{array}{l}\text { Usage } \\
\text { time } \\
\text { (h/year) }\end{array}$ & $\begin{array}{c}\begin{array}{c}\text { Power } \\
\text { consumption } \\
(\mathrm{kWh} / \text { year })\end{array} \\
\end{array}$ & $\begin{array}{l}\text { Power cost } \\
(\text { Won } / \mathrm{kWh})\end{array}$ & $\begin{array}{l}\text { Usage cost } \\
\text { (Won) }\end{array}$ \\
\hline $\begin{array}{c}\text { Fluorescent } \\
\text { lighting fixture }\end{array}$ & 32 & 22,603 & 723,296 & 7,665 & $5,544,064$ & $\begin{array}{c}\text { KRW } \\
107.41\end{array}$ & $595,487,000$ \\
\hline $\begin{array}{l}\text { LED lighting } \\
\text { fixtures }\end{array}$ & 17 & 22,603 & 384,251 & 7,665 & $2,945,284$ & $\begin{array}{l}\text { KRW } \\
107.41\end{array}$ & $316,353,000$ \\
\hline $\begin{array}{l}\text { Smart lighting } \\
\text { control system }\end{array}$ & 17 & 22,603 & 219,023 & 7,665 & $1,678,811$ & $\begin{array}{c}\text { KRW } \\
107.41\end{array}$ & $180,321,000$ \\
\hline $\begin{array}{l}\text { LED lighting } \\
\text { replacement } \\
\text { [Power reduction } \\
(\mathrm{kWh}) / \text { year })]\end{array}$ & \multicolumn{7}{|c|}{$\begin{array}{l}=\text { Power consumption (Fluorescent } 1 \\
\text { lighting fixtures) } \\
=5,544,064 \mathrm{kWh}-2,945,284 \mathrm{kWh} \\
=2,598,780 \mathrm{kWh}\end{array}$} \\
\hline $\begin{array}{l}\text { Smart lighting } \\
\text { control system } \\
\text { [Power reduction } \\
(\mathrm{kWh}) / \text { year] }\end{array}$ & \multicolumn{7}{|c|}{$\begin{array}{l}=\text { Power consumption (Fluorescent lighting } \mathrm{f} \\
\text { lighting fixtures }) \times 0.57 \text { (Energy reduction fad } \\
=5,544,064 \mathrm{kWh}-(2,945,284 \mathrm{kWh} \times 0.57) \\
=3,865,252 \mathrm{kWh}\end{array}$} \\
\hline $\begin{array}{l}\text { Cost reduction } \\
\text { (Won/Year) }\end{array}$ & \multicolumn{7}{|c|}{$\begin{array}{l}=\text { Power reduction }(\mathrm{kWh} / \text { year }) \times \text { Power cost }(\text { Won } / \mathrm{kWh}) \\
=3,865,252 \mathrm{kWh} \times \mathrm{KRW} 107.41 \mathrm{Won} / \mathrm{kWh} \\
=\mathrm{KRW} 415,167,000 \text { Won }\end{array}$} \\
\hline $\begin{array}{l}\mathrm{CO}_{2} \text { reduction } \\
(\mathrm{kgCO} 2 / \text { Year })\end{array}$ & \multicolumn{7}{|c|}{$\begin{array}{l}=\text { Power reduction } \times \mathrm{CO}_{2} \text { Emission factor } \\
=3,865,252 \mathrm{kWh} \times 0.4716 \mathrm{kgCO}_{2} / \mathrm{kWh} \\
=1,822,853 \mathrm{kgCO}_{2} / \text { year }\end{array}$} \\
\hline $\begin{array}{l}\text { Tree planting } \\
\text { effect } \\
\text { (Tree) }\end{array}$ & \multicolumn{7}{|c|}{$\begin{array}{l}=1,822,853\left(\mathrm{kgCO}_{2} / \text { year }\right) / 5\left(\mathrm{kgCO}_{2} / \text { year }\right) \\
=364,571 \text { Trees (Pine tree } 30 \text { years) }\end{array}$} \\
\hline
\end{tabular}


The annual energy consumption of LED lighting compared to the fluorescent lamp of Table 4 was reduced by $2,598,780 \mathrm{kWh}$. In addition, it is found that energy saving of $3,865,252 \mathrm{kWh}$ is achieved by controlling the lighting equipment using smart lighting control system. The annual saving amount can be expected to be economical savings of KRW $415,167,000 \mathrm{Won}$; also, the greenhouse gas savings amounted to $1,822,853 \mathrm{kgCO}_{2} /$ year, yielding 364,571 pine trees.

\section{CONCLUSION}

The effective control of the lighting equipment according to location of the trains will play a significant role in the environmental effects such as energy saving and greenhouse gas reduction, considering that there will be a lot of errors due to the factors that do not reflect the analysis results in Table 4. The purpose of this study is to find the location information of the train with the lighting fixture at a train operation section using a block signal of the railway signal system, and to transmit the information to the smart lighting control system safely for an intelligent smart lighting control system individually or collectively control installed lighting fixtures. And through simulation, it is expected to have significant economic and environmental positive effects by the introduction of intelligent smart lighting system.

In this study, it applied the closed-circuit power line communication method (CPLC), which is the original technology of communication method used in smart lighting control system; application of various communication methods (e.g., LTE-R, LTE, WIFI, ZigBee, Bluetooth, etc.) considering installation environment is also under development. It is currently being tested and installed at Seoul Metro Line 4 to prepare an empirical test and is under preparation of checking the results.

The researchers will strive to develop optimal lighting control algorithms for railway lighting equipment for a more advanced and sustainable future and will continue to share the results.

\section{ACKNOWLEDGEMENT}

This work is supported by the Korea Agency for Infrastructure Technology Advancement (KAIA) grant funded by the Ministry of Land, Infrastructure and Transport (Grant 17CTAPC129797-01).

\section{REFERENCES}

[1] Park, J.-B., Analysis of Environmental Effect by Replacement of Luminaires at Railway Station. Master's thesis, Seoul National University of Science and Technology, 2017.

[2] Park, J.-B. et al., Study on efficient lighting control of urban railway underground tunnel section. KIIEE Annual Spring Conference 2017, pp. 86-86, 2017.

[3] Kim, J. et al., Simulation analysis of lighting control system of subway tunnel section of closed loop power line communication system (CPLC) linked with railway signal system. KIIEE Book No. 32, pp. 27-31, 2018. 